Article

\title{
GDC Buffer Layer Synthesized by Reactive Magnetron Sputtering: Effect of Total Pressure and Thickness on SOFC Performances
}

\author{
Lara Bouleau ${ }^{1}$, Noelia Coton ${ }^{2}$, Pierre Coquoz ${ }^{2}$, Raphael Ihringer ${ }^{2}$, Alain Billard ${ }^{1,3}$ and \\ Pascal Briois 1,3,*(D) \\ 1 FEMTO-ST, UMR 6174, CNRS, Université Bourgogne Franche-Comté, UTBM, Site de Montbéliard, \\ 90010 Belfort, France; 1.bouleau.ca@gmail.com (L.B.); alain.billard@utbm.fr (A.B.) \\ 2 Fiaxell Sàrl, PSE A, Science Park, 1015 Lausanne, Switzerland; noeliacoton@gmail.com (N.C.); \\ pierre.coquoz@gmail.com (P.C.); raphael.ihringer@fiaxell.com (R.I.) \\ 3 FC Lab Research (FR CNRS 3539), Rue Thierry Mieg, F-90010 Belfort, France \\ * Correspondence: pascal.briois@utbm.fr; Tel.: +33-038-458-3701
}

Received: 31 July 2020; Accepted: 27 August 2020; Published: 28 August 2020

check for updates

\begin{abstract}
Gadolinia-doped ceria (GDC) buffer layers were synthesized by reactive magnetron sputtering under different total pressures and different thickness. All as-deposited and after an annealing treatment during two hours under air at $1000{ }^{\circ} \mathrm{C}$ coating presents a face centered cubic (f.c.c) structure of ceria with dense and adhesive morphology. The cell synthesized under $0.1 \mathrm{~Pa}$ and $0.57 \mu \mathrm{m}$ present the best performances. (open-circuit voltage (OCV): $1.133 \mathrm{eV}$ and power density: $1650 \mathrm{~mW} \cdot \mathrm{cm}^{-2} @ 800 \mathrm{~mA} \cdot \mathrm{cm}^{-2}$ at $\left.790{ }^{\circ} \mathrm{C}\right)$.
\end{abstract}

Keywords: buffer layer; GDC; thin film; physical vapor deposition (PVD)

\section{Introduction}

Nowadays, researchers working on the SOFC technology agree that it is necessary to decrease the operating temperature in the range $650-750{ }^{\circ} \mathrm{C}$ of IT-SOFC technology [1-3], which currently is around $850-900{ }^{\circ} \mathrm{C}$ for electrolyte-supported cells used by the three main operators-Bloomenergy, Hexis and Sunfire. At this intermediate temperature (around $700{ }^{\circ} \mathrm{C}$ ), the reactivity-and the cost of the cell components-decreases. Nevertheless, some interactions between the conventional electrolyte material (YSZ) and the cathode material (lanthanum-based) still exist. It is necessary to add a ceria buffer layer to avoid the possible formation of an insulating pyrochlore structure $\mathrm{La}_{2} \mathrm{Zr}_{2} \mathrm{O}_{7}$ layer at the electrolyte-cathode interface [4,5]. In the ceria family, the best material for ionic conductivity is samaria-doped ceria [6]. However, gadolinia-doped ceria is the most employed from the point of view of costs and availability of gadolinium compared to samarium [7]. This buffer layer avoids the reactivity between electrolyte and cathode and presents good anionic conductivity. Therefore, in order to be suitable for the surface treatment process, it must be dense, thin and adherent on electrolyte [8-10]. As the sintering of GDC requires disadvantageously high temperatures [11-14] or the addition of sintering aids, magnetron sputtering allows working at lower temperatures and to have a precise control of the layer thickness. This avoids the formation of a solid solution of YSZ and GDC that occurs above $1300^{\circ} \mathrm{C}$, which is less conductive than YSZ and [15-17]. This technique has been demonstrated successful in hindering strontium diffusion during cell testing, with cathode-deposited-by-electrostatic-spray deposition [8]. 
In this study, we present some recent results obtained on GDC coatings deposited by magnetron sputtering from metallic targets in argon-oxygen reactive gas mixtures with different total pressures and different thicknesses. First, the experimental device is depicted, then the coatings chemical, microstructural and structural characterization (scanning electron microscopy (SEM), X-ray diffraction $(\mathrm{XRD})$ in relation to magnetron sputtering deposition parameters are explained. Second, a complete cell test with a diameter of $25 \mathrm{~mm}$ : Ni-YSZ/YSZ/GDC/LSCF (Yttria stabilized zirconia (YSZ), lanthanum strontium cobalt ferrite (LSCF)) is performed using the Fiaxell open flanges test bench.

\section{Experimental Details}

\subsection{Elaboration of GDC Buffer Layer}

The experimental device was a 100-L Alcatel SCM 650 sputtering chamber pumped down via a system combining XDS35i dry pump and a 5401CP turbo-molecular pump. The sputtering chamber was equipped with three 200-mm-diameter magnetron targets and with a 620 -mm-diameter rotating substrate holder parallel to the targets at a distance of about $110 \mathrm{~mm}$. The distance between the target axis and that of the substrate holder was $170 \mathrm{~mm}$. The Ce-10 at $\% \mathrm{Gd}$ target was supplied via a pulsed-DC advanced-energy dual generator allowing the control of the discharge current, power or voltage. The deposition stage was monitored using a closed loop control plasma emission monitoring system using optical emission spectroscopy. In the present study, the discharge current was fixed at $2.5 \mathrm{~A}$; the bias power applied on the porte substrate holder was $80 \mathrm{~W}$ and the total pressure was around 0.1 or $0.5 \mathrm{~Pa}$ for 10 or $50 \mathrm{sccm}$ argon flow rate. For more details concerning the GDC buffer layer see our previous work focus on the effect of bias power [18].

\subsection{Structural and Morphologic Characterization}

Analysis of the structural features of the coatings were performed in Bragg-Brentano configuration X-ray diffraction using a Bruker D8 focus diffractometer (Co $\mathrm{K}_{\alpha 1+\alpha 2}$ radiations) equipped with the LynxEye linear detector. Diffractograms were collected under air flow during $10 \mathrm{~min}$ in the $\left[20^{\circ}-80^{\circ}\right]$ scattering angle range by steps of $0.019^{\circ}$. Coating thickness was also determined ex situ by using the step method with an Altysurf profilometer produced by Altimet, which allows an accuracy of around $20 \mathrm{~nm}$. Before each measurement, the calibration of the experimental device was realized with a reference sample number 787,569 accredited by CETIM organization. These measurements were systematically confirmed by using SEM observation on the cross section. The coatings morphology was characterized SEM using a JEOL JSM 7800 F, equipped with energy dispersive spectroscopy (EDS) for chemical measurements.

\subsection{Fuel Cell Performances}

Before the cell introduction into the open flange setup, a cathode was deposited on the GDC buffer layer using the screen-printing method. It was composed of 2 layers: the first one-the so-called composite layer-was made by $60 \%$ of LSCF and $40 \%$ of 20GDC. The second layer-the so-called current collection layer (CCL) - was composed only by LSCF. Before printing the CCL, the composite layer was dried at $60{ }^{\circ} \mathrm{C}$ for $20 \mathrm{~min}$ (the same procedure was repeated after the deposition of the CCL). Finally, the cell was sintered in air at $1000{ }^{\circ} \mathrm{C}$ for $2 \mathrm{~h}$. The geometric characteristics of the cathode was a thickness of $18 \mu \mathrm{m}$, a diameter of $14 \mathrm{~mm}$ which gives an active surface of $1.54 \mathrm{~cm}^{2}$. A complete current-voltage (I-V) curve was carried out in the Open Flanges Set-Up developed and commercialized by Fiaxell Sàrl. This test rig allows a simple and rapid mounting of different size cells, ranging from 20 to $80 \mathrm{~mm}$ in diameter and gives highly reproducible results. The distinctiveness of the Open Flanges Set-Up was that no sealing was required: the SOFC cell was simply squeezed between two alumina felts; a nickel foam on the anode side and a grid on the cathode side provided current collection. A scheme of the experimental setup is given in a previous study [18], one can also consult the Fiaxell website (https://fiaxell.com). A fuel flow rate between 100 to $200\left(\mathrm{~mL} . \mathrm{min}^{-1}\right)$, depending on 
the cell size, was enough to ensure an OCV close to the theoretical value as shown for two different cells. Normal operating conditions were cell temperature $=790^{\circ} \mathrm{C}$, hydrogen flow rate $=105 \mathrm{~mL} \cdot \mathrm{min}^{-1}$ (purity $\geq 99.5 \%$ ), air flow rate $=400 \mathrm{~mL} \cdot \mathrm{min}^{-1}$.

\section{Results and Discussion}

In a previous study [18], we highlighted that the synthesis of the buffer layer of GDC of 1- $\mu \mathrm{m}$ thickness, under a total pressure of $0.5 \mathrm{~Pa}$ and the application of a polarization of the sample holder allows to improve the OCV of the fuel cell. As shown in Table 1, a polarization voltage of $80 \mathrm{~W}$ provided the best OCV. This evolution shows that the film grew increasingly dense, which was in agreement with the work of Thornthon and Hoffman [19] and A. Anders [20] who showed that the increase in the energy of the incident species allows a densification of the films. It was possible to increase the energy of the incident species by reducing the working pressure in the enclosure. Indeed, for a lower working pressure the collisions between species present in the plasma were less important, and therefore the energy was more important.

Table 1. Open-circuit voltage (OCV) as a function of the bias power applied on the porte substrate holder.

\begin{tabular}{cc}
\hline Bias Power $(\mathbf{W})$ & OCV $(\mathrm{V})$ \\
\hline 20 & 1.139 \\
\hline 40 & 1.135 \\
\hline 60 & 1.07 \\
\hline 80 & 1.143 \\
\hline
\end{tabular}

\subsection{Influence of the Total Pressure}

In this part, the flow of argon was modified from $50 \mathrm{sccm}$ to $10 \mathrm{sccm}$ which made it possible to reduce the working pressure from $0.5 \mathrm{~Pa}$ to $0.1 \mathrm{~Pa}$. Below $0.1 \mathrm{~Pa}$, the plasma discharge was not stable and it was not possible to realize a 1- $\mu$ m-thick film. As shown in Figure 1a, the two as-deposited films crystallized under face-centered cubic ceria structure, but the film produced under $0.1 \mathrm{~Pa}$ had a preferential orientation according to the diffraction plane (111) and the plane (220) did not diffract. Annealing treatment at $1000{ }^{\circ} \mathrm{C}$ under static air for two hours was carried out, such a treatment was carried out because it was the temperature imposed for obtaining the cathode to made our complete cell and this made it possible to stabilize the GDC layer. Figure $1 \mathrm{~b}$ reveals that the crystallization of the films increased with annealing treatment with the increase in the intensity of the diffraction peaks and the refinement of the peaks, and the diffraction peak (220) appeared on the film produced under the lowest pressure.

SEM observation of the brittle cross section reveals that the films were adherent to the YSZ electrolyte (Figure 2). Figure 2a shows that the as-deposited film processed at $0.5 \mathrm{~Pa}$ had a columnar structure typical of a PVD film in contrast to the film processed at $0.1 \mathrm{~Pa}$ which had a dense structure (Figure 2b). This evolution of morphology as a function of the working pressure in the chamber was in agreement with the work of Thornthon and Hoffman [19] and A. Anders [20] on the densification of coatings with the increase in the energy of the species in the plasma. The annealing heat treatment of the films (Figure 2c,d) increased the densification of the coatings without altering their adhesion. The films were made under reactive conditions and with the closed-loop control system; therefore, the raw films had an oxygen deficit which was made up during the heat treatment. 

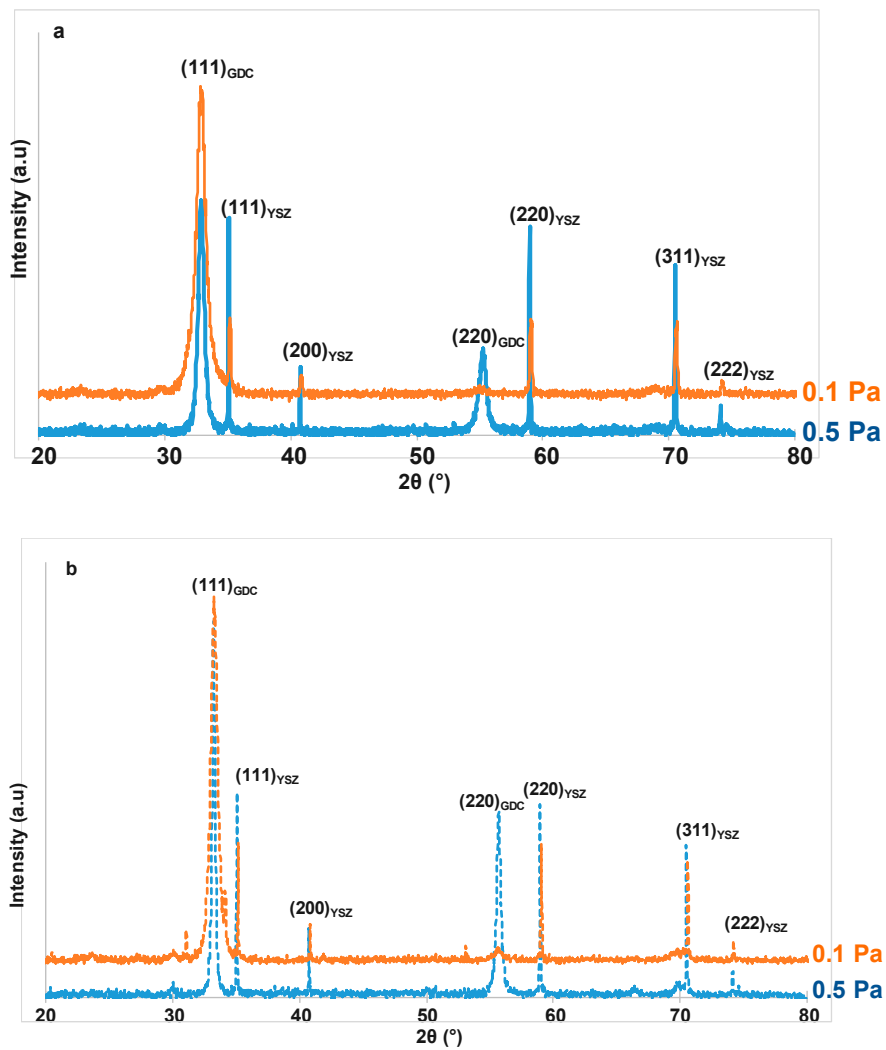

Figure 1. XRD patterns of gadolinia-doped ceria (GDC) coating as function of the total pressure (a: as deposited, b: after annealing treatment under static air for two hours at $1000{ }^{\circ} \mathrm{C}$ ).
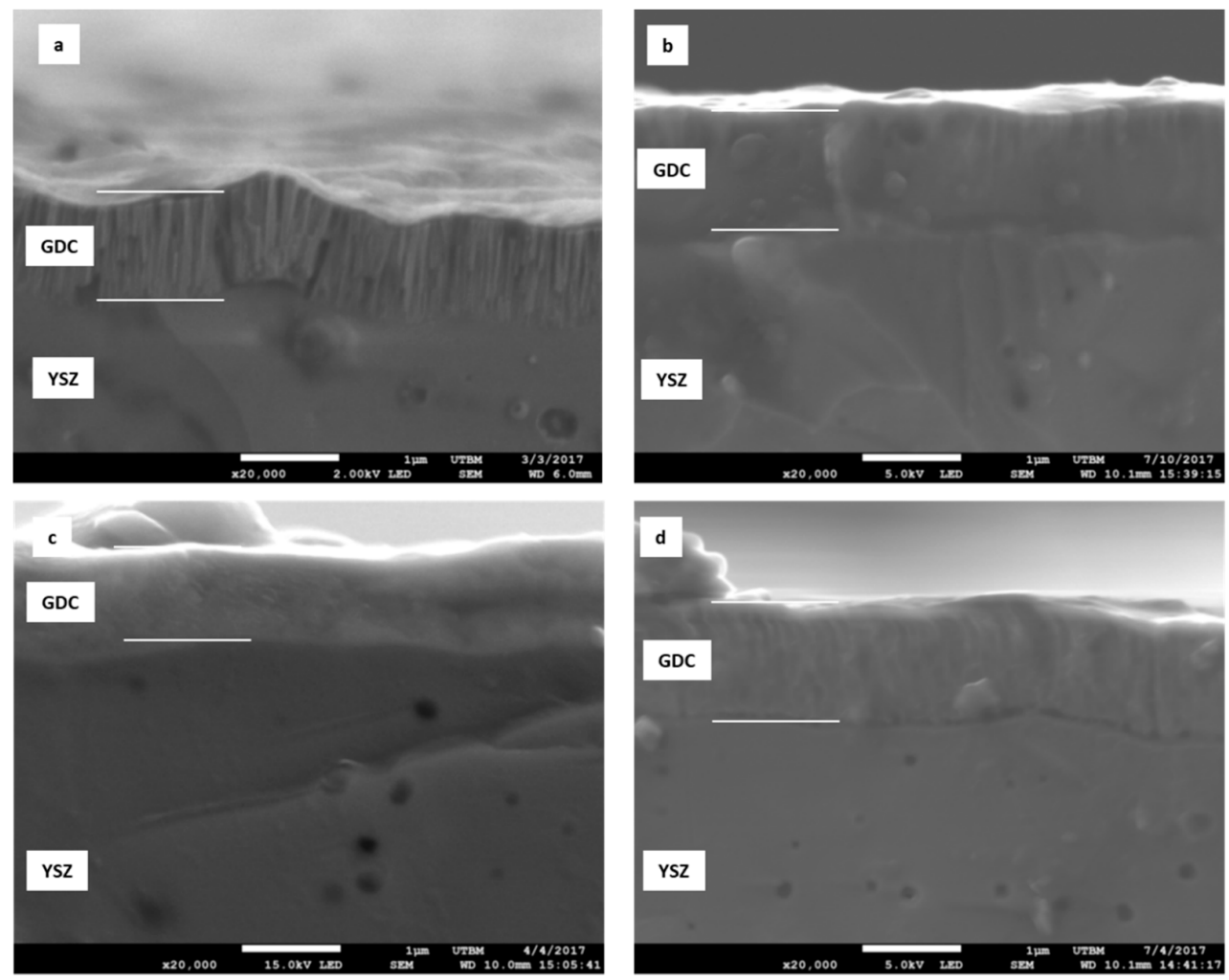

Figure 2. SEM micrographs of GDC coating as function of the total pressure (a,c) $0.5 \mathrm{~Pa}$ and $(\mathbf{b}, \mathbf{d}) 0.1 \mathrm{~Pa}$. $\left(\mathbf{a}, \mathbf{b}\right.$-as deposited; $\mathbf{c}, \mathbf{d}$-after annealing treatment under static air for two hours at $\left.1000{ }^{\circ} \mathrm{C}\right)$. 
Figure 3 shows the electrical measurements carried out in a complete cell. The OCV for the two configurations is relatively close, 1.14 and $1.11 \mathrm{~V}$, respectively for GDC buffer layer synthesized under total pressure 0.5 and $0.1 \mathrm{~Pa}$. However, it appears that the power density is 1000 and $1180 \mathrm{~mW} \cdot \mathrm{cm}^{-2}$ for 0.5 and $0.1 \mathrm{~Pa}$ at a voltage of $0.72 \mathrm{~V}$, which corresponds to an increase of $18 \%$.

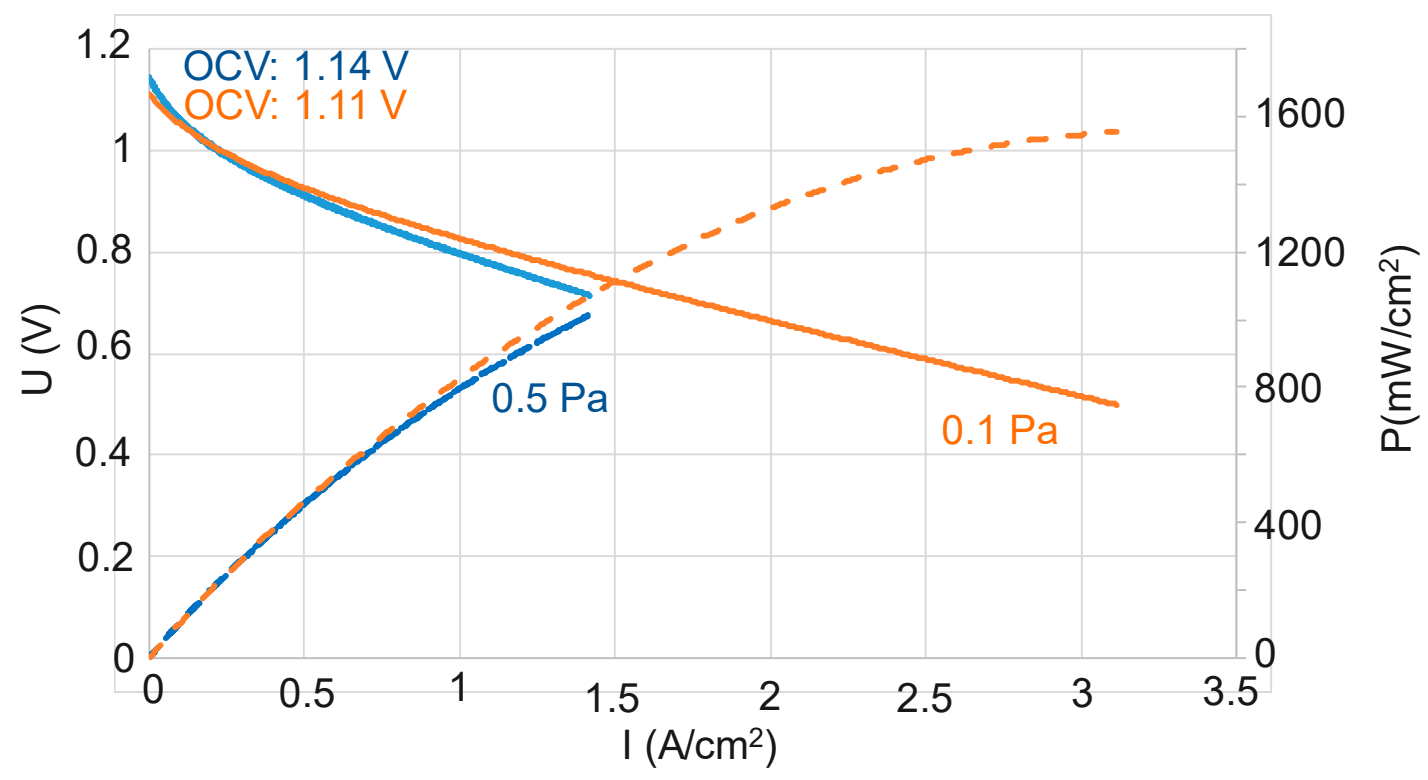

Figure 3. Potential and power versus current of a $2 \mathrm{R}-\mathrm{Cell}^{\mathrm{TM}}$ equipped with a GDC buffer layer deposited via reactive magnetron sputtering under 0.1 and $0.5 \mathrm{~Pa}$.

To conclude this part, under the operating conditions used, it was more favorable to develop the GDC barrier layer under a pressure of $0.1 \mathrm{~Pa}$ to obtain the most interesting fuel cell performance. One of the parameters that influence the performance of a cell was the resistance of the electrolyte. This depends on the nature of the materials, but also on its thickness [8], therefore the next point of this study were to reduce the thickness of the GDC layer in order to observe its effect on the performance of the cell.

\subsection{Effect of GDC Layer Thickness}

The elaboration conditions were those defined above, the deposition time was adjusted to obtain a thickness of about $0.2,0.5$ and $1 \mu \mathrm{m}$. The crystalline structure of the films was the face-centered cubic structure of ceria which was identical to part 3.1. SEM observation of the brittle-fracture cross section (Figure 4) showed that all films were adherent, dense as deposited (Figure $4 \mathrm{a}-\mathrm{c}$ ), and after the annealing heat treatment (Figure $4 \mathrm{~d}-\mathrm{f}$ ) stabilized the GDC layer. The thicknesses were $0.27,0.57$ and $1.088 \mu \mathrm{m}$ for deposition times of 13, 22 and $42 \mathrm{~min}$, respectively

The OCV obtained from the electrical measurements (Figure 5) on the complete cells were 1.098 to $1.13 \mathrm{~V}$, which means that the YSZ electrolyte and the GDC buffer layer were dense, gas tight. Density and tightness were two characteristics necessary for their used as an ionic conductor in a fuel cell [8]. The cell with the $0.57-\mu \mathrm{m}$-thick GDC film reveals the maximum power density of $1650 \mathrm{~mW} \cdot \mathrm{cm}^{-2}$. According to our measurements, the best results were obtained for GDC thickness of $0.57 \mu \mathrm{m}$ and the thicker and thinner layer reveals performance decreased by $30 \%$. When thicknesses were too thin, electric field constriction lines appeared, and the first PVD film growth gauges were often micro-stressed [19], which made it difficult for the species to move in the coating, resulting in a drop in performance. Moreover, in a previous study [9] conducted over longer holding times, we showed that a barrier-layer thickness of $0.5 \mu \mathrm{m}$ was necessary to overcome the reactivity between the electrolyte and the cathode. 

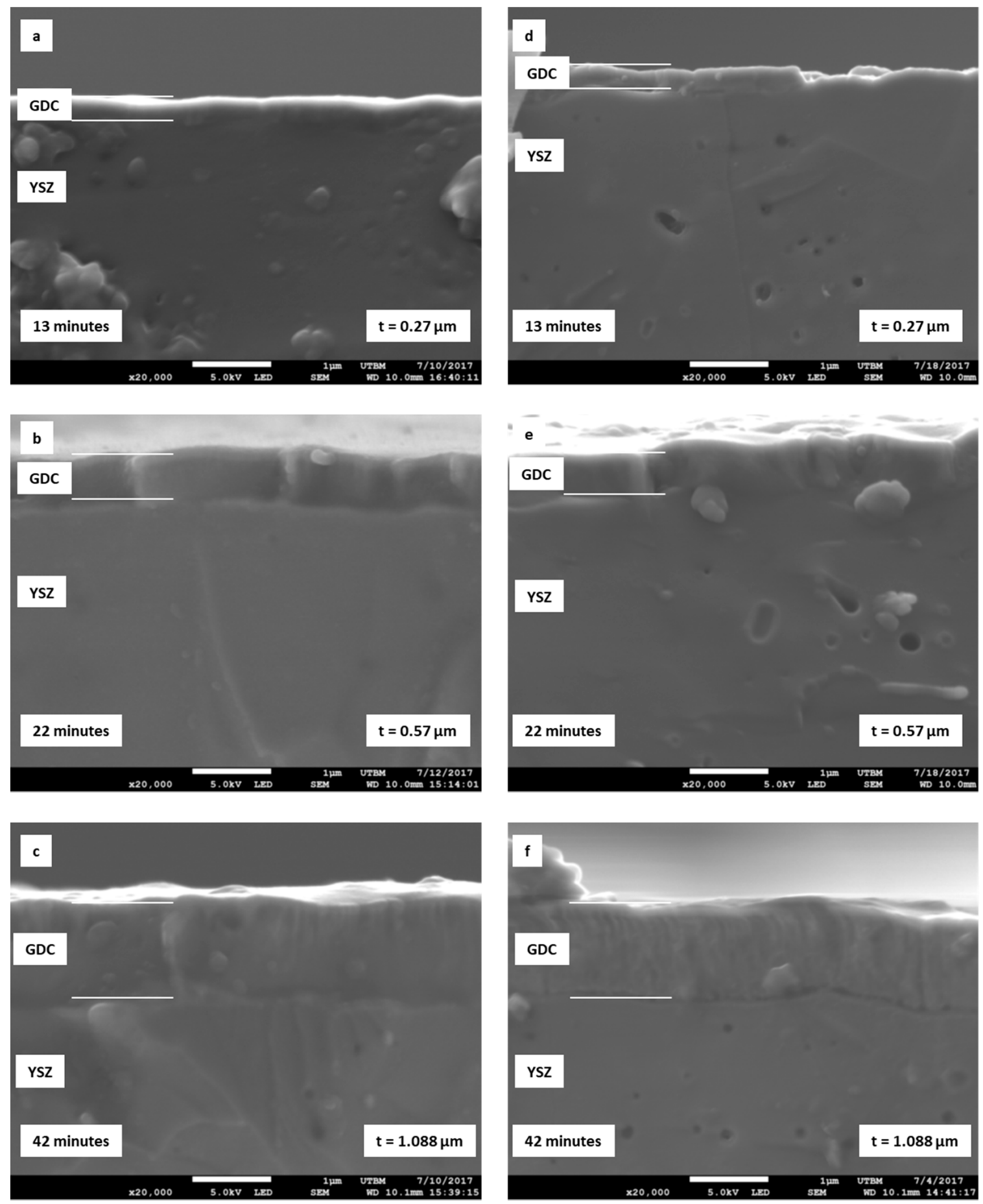

Figure 4. SEM micrographs of GDC coating synthesized under $0.1 \mathrm{~Pa}$ as a function of different thickness. $(\mathbf{a}-\mathbf{c})$ As deposited; (d-f) after annealing treatment under static air for two hours at $\left.1000{ }^{\circ} \mathrm{C}\right)$. 


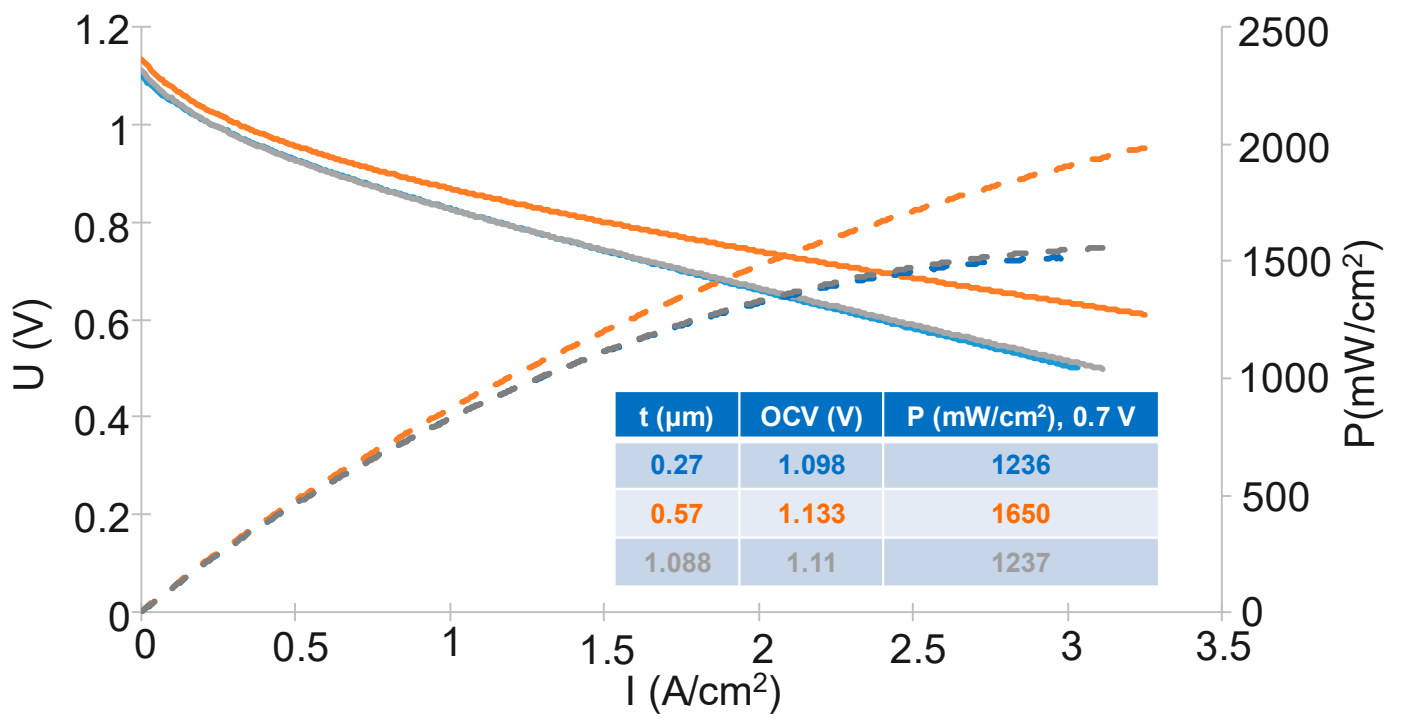

Figure 5. Potential and power versus current of a 2R-Cell ${ }^{\mathrm{TM}}$ equipped with a GDC buffer layer deposited via reactive magnetron sputtering under $0.1 \mathrm{~Pa}$ and different thickness.

\section{Conclusions}

This study completes a previous work [18] on the realization of GDC barrier layers by reactive magnetron sputtering using closed-loop control in order to obtain an acceptable synthesis rate for the transition to SOFC production. In this study, two parameters were studied, namely, the working pressure within the enclosure and the thickness of the GDC layer in order to increase the performance of the complete cell. In all cases, the coatings showed a cubic structure with a centered face of the raw ceramics or after an annealing treatment under static air for $2 \mathrm{~h}$ at $1000^{\circ} \mathrm{C}$ to stabilize the layer. Films which were processed under a pressure of 0.1 Pa reveal a preferential orientation. The SEM observation of the layers showed the quality of the interface and a good compactness after the heat treatment. The electrical measurements showed that the film processed under $0.1 \mathrm{~Pa}, 80 \mathrm{~W}$ polarization on the substrate holder and a thickness of $0.57 \mu \mathrm{m}$ gives the best performance with an OCV and a power density of $1.133 \mathrm{~V}$ and $1650 \mathrm{~mW} \cdot \mathrm{cm}^{-2}$, respectively. It would be good to continue this study in order to define optimal thickness under synthesis conditions, and to carry out long term tests with the best cell of this study in order to study its behavior in time under real conditions of high temperature.

Author Contributions: Conceptualization, P.C., R.I. and P.B.; methodology, P.C. and A.B.; validation, R.I. and P.B.; formal analysis, L.B. and N.C.; investigation, L.B., N.C. and A.B.; resources, L.B., N.C. and A.B.; data curation, L.B. and N.C.; writing — original draft preparation, L.B. and P.B.; writing-review and editing, P.C. and P.B.; visualization, R.I. and P.B.; supervision, R.I. and P.B.; project administration, P.C., R.I. and P.B.; funding acquisition, R.I. and P.B. All authors have read and agreed to the published version of the manuscript.

Funding: This study was carried out within the framework of the European territorial cooperation program INTERREG V A France-Switzerland. The ORCEPAC project has benefitted from financial support from the EU through the European Regional Development Fund (ERDF- €139,176) and the Swiss Confederation's contribution of CHF 134,173. The authors are indebted to the Pays de Montbéliard Agglomération (PMA) for its financial support.

Acknowledgments: This work was done within the FEMTO-ST SURFACE platform.

Conflicts of Interest: The authors declare no conflict of interest.

\section{References}

1. Huijsmans, J.P.P.; Van Berkel, F.P.F.; Christie, G.M. Intermediate temperature SOFC-A promise for the 21st century. J. Power Sources 1998, 71, 107-110. [CrossRef]

2. Mc Evoy, A.J. Thin SOFC electrolytes and their interfaces-A near-term research strategy. Solid State Ion. 2000, 132, 159-165. [CrossRef] 
3. Boudghene Stambouli, A.; Traversa, E. Solid oxide fuel cells (SOFCs): A review of an environmentally clean and efficient source of energy. Renew. Sustain. Energy Rev. 2002, 6, 433-455. [CrossRef]

4. Harboe, S.; Sohn, Y.J.; Guillon, O.; Menzler, N.H. Investigation of LSM-8YSZ cathode within an all ceramic SOFC. Part I: Chemical interactions. J. Eur. Ceram. Soc. 2020, 40, 3608-3617. [CrossRef]

5. Wang, W.; Hu, S.; Han, Y.; Pan, X.; Xu, Q.; Zhu, J. Interaction of Zr with oxidized and partially reduced ceria thin films. Surf. Sci. 2016, 653, 205-210. [CrossRef]

6. Eguchi, K.; Setoguchi, T.; Inoue, T.; Arai, H. Electrical properties of ceria-based oxides and their application to solid oxide fuel cells. Solid State Ion. 1992, 52, 165-172. [CrossRef]

7. Choi, J.; Park, D.; Seon, B.; Bae, H. Low-temperature preparation of dense (Gd,Ce) $\mathrm{O}_{2-\delta}-\mathrm{Gd}_{2} \mathrm{O}_{3}$ composite buffer layer by aerosol deposition for YSZ electrolyte-based SOFC. Int. J. Hydrog. Energy 2012, 37, 9809-9815. [CrossRef]

8. Ivers-Tiffée, E.; Weber, A.; Herbstritt, D. Materials and technologies for SOFC-components. J. Eur. Ceram. Soc. 2001, 21, 1805-1811. [CrossRef]

9. Constantin, G.; Rossignol, C.; Briois, P.; Billard, A.; Dessemond, L.; Djurado, E. Efficiency of a dense thin CGO buffer layer for solid oxide fuel cell operating at intermediate temperature. Solid State Ion. 2013, 249-250, 98-104. [CrossRef]

10. Choi, H.; Na, Y.; Kwak, M.; Kim, T.W.; Seo, D.; Woo, S.; Kim, S. Development of solid oxide cells by co-sintering of GDC diffusion barriers with LSCF air electrode. Ceram. Int. 2017, 43, 13653-13660. [CrossRef]

11. Fu, Y.-P.; Chen, S.-H. Preparation and characterization of neodymium-doped ceria electrolyte materials for solid oxide fuel cells. Ceram. Int. 2010, 36, 483-490. [CrossRef]

12. Kang, Y.J.; Choi, G.M. The effect of alumina and $\mathrm{Cu}$ addition on the electrical properties and the SOFC performance of Gd-doped $\mathrm{CeO}_{2}$ electrolyte. Solid State Ion. 2009, 180, 886-890. [CrossRef]

13. Zha, S. Ni-Ce ${ }_{0.9} \mathrm{Gd}_{0.1} \mathrm{O}_{1.95}$ anode for GDC electrolyte-based low-temperature SOFCs. Solid State Ion. 2004, 166, 241-250. [CrossRef]

14. Nagamori, M.; Shimonosono, T.; Sameshima, S.; Hirata, Y.; Matsunaga, N.; Sakka, Y. Densification and Cell Performance of Gadolinium-Doped Ceria (GDC) Electrolyte/NiO-GDC Anode Laminates. J. Am. Ceram. Soc. 2009, 92, S117-S121. [CrossRef]

15. Sammes, N.M.; Tompsett, G.A.; Cai, Z. The chemical reaction between ceria and fully stabilised zirconia. Solid State Ion. 1999, 121, 121-125. [CrossRef]

16. Tsoga, A.; Gupta, A.; Nikolopoulos, P. Gadolinia-doped ceria and yttria stabilized zirconia interfaces: Regarding their application for SOFC technology. Acta Mater. 2000, 48, 4709-4714. [CrossRef]

17. Constantin, G.; Rossignol, C.; Barnes, J.-P.; Djurado, E. Interface stability of thin, dense CGO film coating on YSZ for solid oxide fuel cells. Solid State Ion. 2013, 235, 36-41. [CrossRef]

18. Breaz, E.; Aubry, E.; Billard, A.; Coton, N.; Coquoz, P.; Pappas, A.; Diethelm, S.; Ihringer, R.; Briois, P. Influence of the Bias Substrate Power on the GDC Buffer Layer. ECS Trans. 2017, 78, 807-816. [CrossRef]

19. Thornton, J.A.; Hoffman, D.W. Stress related effect in thin films. Thin Solid Film 1989, 171, 5-31. [CrossRef]

20. Anders, A. A structure zone diagram including plasma-based deposition and ion etching. Thin Solid Film 2010, 518, 4087-4090. [CrossRef]

(C) 2020 by the authors. Licensee MDPI, Basel, Switzerland. This article is an open access article distributed under the terms and conditions of the Creative Commons Attribution (CC BY) license (http://creativecommons.org/licenses/by/4.0/). 